\title{
Analysis of corneal endothelial cell density and morphology after laser in situ keratomileusis using two types of femtosecond lasers
}

This article was published in the following Dove Press journal:

Clinical Ophthalmology

21 September 2012

Number of times this article has been viewed

Minoru Tomita ${ }^{1,2, *}$

George O Waring IV 3,4

Miyuki Watabe ${ }^{1, *}$

'Shinagawa LASIK Center, Chiyoda-ku, Tokyo, Japan; ${ }^{2}$ Department of Ophthalmology, Wenzhou Medical College, Wenzhou, China; ${ }^{3}$ Medical University of South Carolina, Storm Eye Institute, Charleston, SC, USA; ${ }^{4}$ Magill Laser Center, Charleston, SC, USA

*These authors contributed equally to this study
Correspondence: Minoru Tomita Shinagawa Lasik Center, Yurakucyo ITOCiA I4F, 2-7-I Yurakucyo, Chiyodaku, Tokyo, I00-0006, Japan Tel $+8 \mid 3522$ I8I 37 Fax $+8 \mid 3522$ I3I 38 Email tomita@shinagawa-lasik.com
Purpose: To compare two different femtosecond lasers used for flap creation during laser-assisted in situ keratomileusis (LASIK) surgery in terms of their effects on the corneal endothelium.

Methods: We performed LASIK surgery on 254 eyes of 131 patients using IntraLase FS60 (Abbott Medical Optics, Inc, Irvine, CA; IntraLase group) and 254 eyes of 136 patients using Femto LDV (Ziemer Group AG, Port, Switzerland; LDV group) for corneal flap creation. The mean cell density, coefficient of variation, and hexagonality of the corneal endothelial cells were determined and the results were statistically compared.

Results: There were no statistically significant differences in the corneal morphology between pre and post LASIK results in each group, nor were there significant differences between the results of both groups at 3 months post LASIK.

Conclusions: Both IntraLase FS60 and Ziemer Femto LDV are able to create flaps without significant adverse effects on the corneal endothelial morphology through 3 months after LASIK surgery.

Keywords: LASIK, corneal endothelium, femtosecond laser, IntraLase FS60, Ziemer LDV

\section{Introduction}

The effectiveness, safety, and stability of using laser-assisted in situ keratomileusis (LASIK) for the correction of refractive errors have been well documented. Early in the development of LASIK, complications related to the use of microkeratomes were reported. These complications included free caps, flap button holes, and instances of suction loss. ${ }^{1-3}$ When compared to manual microkeratomes, femtosecond lasers create flaps with more planar architectures and also improve the precision of flap thickness. ${ }^{4,5}$ Several femtosecond lasers, including the IntraLase FS ${ }^{\text {TM }}$ series (Abbott Medical Optics, Inc, Irvine, CA), FEMTEC ${ }^{\circledR}$ (20/10 Perfect Vision Optische Geraete GmbH, Heidelberg, Germany), VisuMax ${ }^{\circledR}$ (Carl Zeiss Meditec, Jena, Germany), and Femto LDV (Ziemer Group AG, Port, Switzerland) have been introduced, and the technology has progressed rapidly.

In our clinic, we routinely use both IntraLase FS60 and Femto LDV for lamellar flap creation. The safety of using IntraLase ${ }^{\mathrm{TM}}$ femtosecond lasers in terms of the effects on corneal endothelial cells has been documented in the literature, as well as at our clinic. ${ }^{6,7}$ To our knowledge, the effects of using Femto LDV on corneal endothelial cells have not been reported elsewhere. In this study, we compared corneal endothelial cell density (ECD), coefficient of variation (CV), and endothelial cell hexagonality changes after LASIK surgery using both IntraLase FS60 and Femto LDV. The level 
of safety, the relative changes in ECD, residual bed thickness in response to changes in the amount of LASIK correction attempted, as well as each patient's age were also studied.

\section{Materials and methods}

\section{Patients' information}

In this retrospective comparative analysis, we included patients who visited our clinic for preoperative screening and who underwent LASIK surgery between February and December 2009. Patients were randomly selected, and patients who did not return for follow up visits were excluded from the study. As a result, 254 eyes of 136 patients (male: 94 eyes of 50 patients; female: 160 eyes of 86 patients) who underwent LASIK surgery using Femto LDV (Ziemer Group AG) between April 2009 and December 2009 (LDV group) at the Shinagawa Lasik Center in Tokyo, and 254 eyes of 131 patients (male: 99 eyes of 50 patients; female: 155 eyes of 81 patients) who underwent LASIK using IntraLase FS60 (Abbott Medical Optics) between February 2009 and December 2009 (IntraLase group) at the Shinagawa Lasik Center in Tokyo, Japan were included in the study. All the surgical as well as the pre and postoperative procedures were thoroughly explained to all participating patients, and the patients signed informed consent forms before undergoing the procedure.

The mean age of the patients in the LDV group was $33.6 \pm 8.4$ years (range: 20 to 59 years), while the mean age of the patients in the IntraLase group was $33.3 \pm 7.2$ years (range: 18 to 52 years). The mean residual corneal bed thickness for the LDV group was $359 \pm 34 \mu \mathrm{m}$ (range: 296 to
$456 \mu \mathrm{m})$, and the mean residual corneal bed thickness for the IntraLase group was $367 \pm 34 \mu \mathrm{m}$ (range: 302 to $469 \mu \mathrm{m}$ ). The residual bed thickness was predicted using preoperative pachymetry, attempted flap thickness, and predicted ablation depth. The amount of intended refractive error corrected for both the LDV group and IntraLase group was $-5.32 \pm 2.24 \mathrm{D}$ (range: -1.50 to $-15.88 \mathrm{D}$ ) and $-4.75 \pm 2.05 \mathrm{D}$ (range: -1.13 to $-12.75 \mathrm{D})$, respectively, for the initial correction. None of the eyes had undergone an enhancement or eye surgery prior to the LASIK procedure. Prior to the LASIK surgery, patients used glasses and/or contact lenses to compensate for their refractive error. The period between the cessation of contact lens use and preoperative screening is shown in Table 1. For the FS60 group, the number and percentage of patients who were wearing soft contact lenses (SCL), hard contact lenses (HCL), both SCL/HCL, and glasses prior to LASIK surgery was $67(51.1 \%), 19(14.5 \%), 20(15.3 \%)$, and $23(17.6 \%)$, respectively. The number of patients in the LDV group who wore SCL, HCL, both SCL/HCL, and glasses prior to the LASIK procedure was 68 (50.0\%), 23 (16.9\%), 17 (12.5\%), and $28(20.6 \%)$, respectively.

\section{Surgical procedure}

Either Femto LDV or IntraLase FS60 was used to create a lamellar flap. The attempted thickness of the flap created using Femto LDV ranged from 90 to $110 \mu \mathrm{m}$ (mean: $98 \pm 9 \mu \mathrm{m}$ ), and from 85 to $100 \mu \mathrm{m}$ (mean: $93 \pm 6 \mu \mathrm{m}$ ) using IntraLase FS60. Femtosecond laser settings included a pulse energy of 20 to $100 \mathrm{~nJ}$ when Femto LDV was used, and both a bed energy of $0.90 \mu \mathrm{J}$ and a side cut energy of $0.90 \mu \mathrm{J}$ when

Table I Period between cessation of contact lens use and preoperative screening

\begin{tabular}{|c|c|c|c|c|c|c|c|c|c|c|}
\hline \multirow[t]{2}{*}{ Length } & \multicolumn{5}{|c|}{ FS60 group } & \multicolumn{5}{|c|}{ LDV group } \\
\hline & Total & SCL only & HCL only & Both & No answer & Total & SCL only & HCL only & Both & No answer \\
\hline 7 days & 31 & 25 & 0 & 6 & 0 & 32 & 29 & 0 & 3 & 0 \\
\hline 14 days & 38 & 20 & II & 7 & 0 & 44 & 28 & 10 & 6 & 0 \\
\hline 21 days & 10 & 6 & 3 & 0 & 1 & 13 & 3 & 8 & 2 & 0 \\
\hline 30 days & 10 & 6 & 3 & I & 0 & 4 & 0 & 1 & 3 & 0 \\
\hline 60 days & 1 & I & 0 & 0 & 0 & I & I & 0 & 0 & 0 \\
\hline 90 days & 5 & 2 & $\mathrm{I}^{\mathrm{a}}$ & 2 & 0 & 3 & 2 & 1 & 0 & 0 \\
\hline 120 days & 1 & 0 & 0 & I & 0 & 2 & I & 1 & 0 & 0 \\
\hline I50 days & 1 & 0 & 0 & 1 & 0 & I & 0 & 0 & 1 & 0 \\
\hline 180 days & 3 & 1 & I & 1 & 0 & 3 & 2 & I & 0 & 0 \\
\hline I year & I & I & 0 & 0 & 0 & I & I & 0 & 0 & 0 \\
\hline 2 years & 3 & 3 & 0 & 0 & 0 & 2 & I & 1 & 0 & 0 \\
\hline 3 years & 2 & 1 & 0 & 1 & 0 & - & - & - & - & - \\
\hline 3.5 years & - & - & - & - & - & 1 & 0 & 0 & 1 & 0 \\
\hline 5 years & - & - & - & - & - & I & 0 & 0 & I & 0 \\
\hline 8 years & 1 & 1 & 0 & 0 & 0 & - & - & - & - & - \\
\hline
\end{tabular}

Note: arthokeratology contact lens user.

Abbreviations: SCL, soft contact lenses; $\mathrm{HCL}$, hard contact lenses. 
IntraLase FS60 was used. The repetition rate of the pulse was $1 \mathrm{MHz}$ for Femto LDV and $60 \mathrm{kHz}$ for IntraLase FS60. Given that the spot size $(>1 \mu \mathrm{m})$ and energy of IntraLase FS60 is larger than that of Femto LDV (spot size: $<1 \mu \mathrm{m}$ ), and given that the cutting process is driven by mechanical forces disrupting the surrounding tissues, the spot and line separation of IntraLase FS60 is larger than that of Femto LDV. Since smaller spot energy was used by Femto LDV, the disruption occurred locally, resulting in more pulses being required for disruption. After flap creation, excimer laser ablation for refractive correction was performed using ALLEGRETTO WAVE Eye-Q ${ }^{\circledR} 400$ Hz (WaveLight; Alcon Laboratories, Inc, Ft Worth, TX) for all eyes.

\section{Endothelial cell analysis}

In order to evaluate the effects of using femtosecond lasers on corneal endothelial cells both preoperatively and 3 months postoperatively, $\mathrm{ECD}, \mathrm{CV}$, and hexagonality were measured with a noncontact specular microscope (Noncon ROBO FA-3509 ${ }^{\circledR}$; Konan Medical, Inc, Hyogo, Japan), and the results were compared. The measurement was taken from the central cornea. The preoperative and 3 months postoperative ECD were calculated using the center method. Fifty cells were dotted manually by clicking the center of the cells with a mouse. After doing so, the ECD was estimated, and the cell's morphology was examined for both $\mathrm{CV}$ and hexagonality. The postoperative ECD was adjusted by employing the formula demonstrated by Nawa et al, ${ }^{8}$ as the magnification after the LASIK procedure was altered and the amount of endothelial cells were over or underestimated. ${ }^{9}$

\section{Statistical analysis}

In order to evaluate the different effects of using two femtosecond lasers on ECD and corneal endothelial morphologies, statistical analysis of the results was performed using either Student's $t$-test, paired Student's $t$-test, or Mann-Whitney's $U$-test where applicable. When comparing the relative differences in ECD, CV, and hexagonal changes at 3 months postoperatively to the preoperative values, Pearson's correlation coefficient was used to determine if there was any relationship with the following parameters: the residual bed thickness, the amount of LASIK correction, and/or the patient's age. Statistical differences with $P<0.05$ were considered significant.

\section{Results}

\section{Corneal endothelial analysis}

The ECD, CV, and hexagonality of the patients' eyes both preoperatively and 3 months postoperatively were measured and compared (Table 2). No statistically significant differences were found in ECD, CV, and hexagonality between the LDV and IntraLase groups. In addition, no significant difference was observed in pre and postoperative values within the groups (Student's $t$-test, Mann-Whitney's $U$-test, and paired Student's $t$-test, $P>0.05)$. The mean change in $\mathrm{ECD}, \mathrm{CV}$, and hexagonality were $-17 \pm 247$ cells $/ \mathrm{mm}^{2}$ (a $0.58 \%$ decrease), $-0.1 \pm 9.9$ (a $0.30 \%$ decrease), and $1.0 \% \pm 13.8 \%$ (a $1.75 \%$ increase) in the LDV group, respectively. The mean change in ECD, CV, and hexagonality were $22 \pm 313$ cells $/ \mathrm{mm}^{2}$ (a $0.76 \%$ increase), $-0.5 \pm 8.8$ (a $1.47 \%$ decrease), and $-0.3 \% \pm 9.6 \%$ (a $0.52 \%$ decrease) in the IntraLase group, respectively (Student's $t$-test $P=0.1273,0.7522$, and 0.3198 , respectively).

Table 2 Endothelial cell density and morphology preoperatively and 3 months postoperatively taken from the center of the cornea

\begin{tabular}{|c|c|c|c|c|c|}
\hline & $\begin{array}{l}\text { Pre-op } \\
(\text { Mean } \pm \text { SD) }\end{array}$ & $P$-value & $\begin{array}{l}3 \text { months } \\
(\text { Mean } \pm \text { SD) }\end{array}$ & $P$-value & $\begin{array}{l}\text { Significance between pre } \\
\text { and } 3 \text { months post-op ( } P \text {-value) }\end{array}$ \\
\hline \multicolumn{6}{|l|}{ ECD (cells/mm²) } \\
\hline $\begin{array}{l}\text { IntraLase group } \\
(\mathrm{n}=254)\end{array}$ & $2913 \pm 348$ & $0.8529^{a}$ & $2935 \pm 354$ & $0.2688^{a}$ & $0.4868^{\mathrm{b}}$ \\
\hline $\begin{array}{l}\text { LDV group } \\
(\mathrm{n}=254)\end{array}$ & $2919 \pm 328$ & & $2902 \pm 308$ & & $0.287 I^{b}$ \\
\hline \multicolumn{6}{|l|}{ CV } \\
\hline $\begin{array}{l}\text { IntraLase group } \\
(\mathrm{n}=254)\end{array}$ & $34 \pm 7$ & $0.3816^{a}$ & $33 \pm 6$ & $0.3844^{c}$ & $0.3855^{\mathrm{b}}$ \\
\hline $\begin{array}{l}\text { LDV group } \\
(\mathrm{n}=254)\end{array}$ & $33 \pm 6$ & & $33 \pm 8$ & & $0.9192^{b}$ \\
\hline \multicolumn{6}{|l|}{ Hexagonality (\%) } \\
\hline $\begin{array}{l}\text { IntraLase group } \\
(\mathrm{n}=254)\end{array}$ & $58 \pm 11$ & $0.4978^{a}$ & $58 \pm 11$ & $0.5675^{a}$ & $0.8934^{b}$ \\
\hline $\begin{array}{l}\text { LDV group } \\
(\mathrm{n}=254)\end{array}$ & $57 \pm 11$ & & $58 \pm 11$ & & $0.2637^{b}$ \\
\hline
\end{tabular}

Notes: ${ }^{a}$ Student's $t$-test; ${ }^{b}$ paired Student's $t$-test; 'Mann-Whitney's U-test. Abbreviations: ECD, endothelial cell density; CV, coefficient of variation. 


\section{Factors affecting ECD, CV, and hexagonality over time}

The correlation coefficient between the change in ECD, $\mathrm{CV}$, and hexagonality in association with the patients' ages, residual bed thickness, and amount of refractive correction were evaluated. In the LDV group, the patient's ECD change and the amount of correction, as well as the patient's age and the change in $\mathrm{CV}$ demonstrated a statistically significant correlation $(P=0.0138, r=-0.154 ; P=0.0203, r=0.145$, respectively). However, with this low correlation coefficient value, there may not be sufficient evidence to prove an actual correlation between the factors. Other factors did not show statistical significance during this comparison.

\section{Discussion}

Various studies have been performed evaluating the effect of refractive surgery on the corneal endothelium. Excimer lasers used for photorefractive keratectomy (PRK) have been reported to have no adverse effects on the corneal endothelium. ${ }^{10}$ Similarly, LASIK surgery conducted with a mechanical microkeratome has also been demonstrated to have no effect on the corneal endothelium. ${ }^{11,12}$ Since obtaining Food and Drug Administration approval in 2001, a vast number of surgeries have been completed worldwide (including in Japan) using the IntraLase ${ }^{\mathrm{TM}}$ femtosecond laser. Reported benefits include more predictable flap thicknesses and planarity, and fewer intraoperative flap complications. ${ }^{13-15}$ In our clinic, various versions of the IntraLase $^{\mathrm{TM}}$ femtosecond lasers including FS, FS30, and FS60 have been used. Previously, we reported that the use of IntraLase FS60 for LASIK surgery did not result in damage to the corneal endothelium. ${ }^{7}$

By comparing the ECD changes of post photorefractive keratotomy and post thin-flap LASIK surgery using the IntraLase FS60, Smith et al ${ }^{15}$ reported that there were no statistically significant changes at 3 months after the PRK or the LASIK procedure when compared to the preoperative value. Furthermore, statistical significance was not observed between the two groups when comparing the ECD changes preoperatively and 3 months after the PRK or the LASIK surgery. ${ }^{15}$ In addition, Sonigo et $\mathrm{al}^{16}$ reported that when post-LASIK (femtosecond laser or microkeratome) confocal microscopy images of the endothelial cells were compared, no significant changes were seen in the endothelial morphology over a 12-month observation period.

Currently, a number of femtosecond laser models are available. The technical differences between Femto LDV and IntraLase FS60 are worth describing. The spot size for Femto LDV is less than $1 \mu \mathrm{m}$, while the spot size for IntraLase FS60 is more than $1 \mu \mathrm{m} .{ }^{17}$ The pulse energy for Femto LDV is about 20 to $100 \mathrm{~nJ}$, while the IntraLase FS60 is $1 \mu \mathrm{J}$. The repetition rate for Femto LDV is higher $(1 \mathrm{MHz})$ than the $60 \mathrm{kHz}$ noted for IntraLase. ${ }^{17}$ In addition, the cutting process of the IntraLase FS60 is driven by mechanical forces, which disrupt an area of tissue that is larger than the spot size. The cutting process of the Femto LDV differs given that the disruption is confined to the focal spot size of the laser pulse, which results in more pulses being required in order to cut the same area. ${ }^{17}$ With the IntraLase FS60, the energy per pulse is higher than the individual pulse energy of the Femto LDV; however, the total energy used for flap creation was higher when Femto LDV was used since the total number of pulses required was higher.

It has been demonstrated that keratocyte apoptosis and postoperative inflammation after LASIK procedures occur in association with use of high pulse energy femtosecond lasers. ${ }^{18,19}$ Moreover, it has been reported that the difference in the cutting processes could affect flap creation, especially if the patients had corneal opacity. ${ }^{20}$ The mechanical forces produced by IntraLase FS60 could break through Bowman's layer when it disrupts sections with corneal opacity, while Femto LDV is able to disrupt opacity without a problem. ${ }^{20}$ In our study, we observed that ECD, CV, and endothelial cell hexagonality were stable at 3 months after LASIK surgery in both the LDV and the IntraLase groups.

At 3 months post LASIK surgery, the mean ECD as measured from the center of the cornea increased by $0.76 \%$ in the IntraLase group, and the mean hexagonal cell percentage increased by $1.75 \%$ in the LDV group. These increases were not statistically significant when comparing the values preoperatively and 3 months postoperatively. Prior to LASIK surgery, a majority of the patients were wearing soft and/or hard contact lenses, but stopped their use after the LASIK procedure. Sheng and Bullimore ${ }^{21}$ demonstrated that wearing contact lenses was the most significant factor affecting morphological and ECD count change of the endothelium. It has been reported that stopping the use of contact lenses may be related to an increase in central ECD as peripheral cells reposition to the central area. ${ }^{22,23}$ Furthermore, positive morphological changes such as a decrease in $\mathrm{CV}$ and an increase in hexagonal cell percentage have also been reported to have a relation to the termination of contact lens use. ${ }^{23}$ These reports may explain 
why we observed an increase in the ECD and hexagonal cell percentages in our study.

On the other hand, Amoozadeh et $\mathrm{al}^{24}$ suggested that the increase in ECD can be attributed to sampling errors before and after surgery since endothelial cells did not divide. Additionally, Trocmé et $\mathrm{a}^{25}$ hypothesized that the rearrangement of cells may have masked the true damage of the endothelial cells caused by refractive surgery, and suggested longer term observation in future studies. Nonetheless, we did not observe statistically significant differences between $\mathrm{ECD}, \mathrm{CV}$, and hexagonal cell percentage in either the IntraLase or the LDV groups either preoperatively or 3 months postoperatively.

Patel and Bourne ${ }^{26}$ reported that in 9 years of observation, they did not see any significant relationships between ECD reduction and either the amount of refractive correction nor the residual bed thickness after LASIK surgery. They did not mention noting any relationships between $\mathrm{CV}$ and hexagonal cell percentage with other factors such as the amount of refractive correction, residual bed thickness, or patient age. In our study, there were no significant correlations between $\mathrm{ECD}, \mathrm{CV}$, and hexagonal cell percentage with the amount of refractive correction, residual bed thickness, or patient age in either the IntraLase or the LDV groups at 3 months after LASIK surgery. The limitation to our study is the short follow-up time; yet, our results were consistent with prior reports by Patel and Bourne ${ }^{26}$ describing the lack of any correlation between ECD reduction and the amount of refractive correction or residual bed thickness after LASIK surgery.

In conclusion, the use of either Femto LDV or IntraLase FS60 femtosecond lasers for lamellar flap creation did not appear to have an adverse effect on ECD and/or endothelial morphology. Longer follow up is needed in order to confirm the long-term effect of femtosecond laser use on the corneal endothelium.

\section{Disclosure}

Dr Tomita is a consultant for AcuFocus, Inc and Ziemer Group AG. The other authors report no conflict of interest with this submission. No financial support was received for this submission.

\section{References}

1. Binder PS. One thousand consecutive IntraLase laser in situ keratomileusis flaps. J Cataract Refract Surg. 2006;32(6):962-969.

2. Lichter H, Stulting RD, Waring GO 3rd, Russell GE, Carr J. Buttonholes during LASIK: etiology and outcome. J Refract Surg. 2007;23(5): 472-476.
3. Al-Mezaine HS, Al-Amro SA, Al-Obeidan S. Incidence, management, and visual outcomes of buttonholed laser in situ keratomileusis flaps. $J$ Cataract Refract Surg. 2009;35(5):839-845.

4. Zhou Y, Tian L, Wang N, Dougherty PJ. Anterior segment optical coherence tomography measurement of LASIK flaps: femtosecond laser vs microkeratome. J Refract Surg. 2011;27(6):408-416.

5. Stahl JE, Durrie DS, Schwendeman FJ, Boghossian AJ. Anterior segment OCT analysis of thin IntraLase femtosecond flaps. J Refract Surg. 2007;23(6):555-558.

6. Muñoz G, Albarrán-Diego C, Sakla HF, Ferrer-Blasco T, Javaloy J. Effects of LASIK on corneal endothelium using the $15-\mathrm{kHz}$ IntraLase femtosecond laser. J Refract Surg. 2011;27(9):672-677.

7. Tomita M, Watabe M, Waring GO 4th, Durrie DS. Corneal endothelial cell density after myopic intra-LASIK and the effect of AC gas bubbles on the corneal endothelium. Eur J Ophthalmol. 2011;21(4): 363-367.

8. Nawa Y, Ueda T, Masuda K, Ishibashi H, Hara Y, Uozato H. Evaluation of the corneal endothelium after hyperopic laser in situ keratomileusis. J Cataract Refract Surg. 2003;29(8):1543-1545.

9. Amano S, Shimizu K. Corneal endothelial changes after excimer laser photorefractive keratectomy. Am J Ophthalmol. 1993;116(6): 692-694.

10. Pérez-Santonja JJ, Sahla HF, Alió JL. Evaluation of endothelial cell changes 1 year after excimer laser in situ keratomileusis. Arch Ophthalmol. 1997;115(7):841-846.

11. Simaroj P, Kosalprapai K, Chuckpaiwong V. Effect of laser in situ keratomileusis on the corneal endothelium. J Refract Surg. 2003; 19(Suppl 2):S237-S240.

12. Kim JY, Kim MJ, Kim TI, Choi HJ, Pak JH, Tchah H. A femtosecond laser creates a stronger flap than a mechanical microkeratome. Invest Ophthalmol Vis Sci. 2006;47(2):599-604.

13. Knorz MC, Vossmerbaeumer U. Comparison of flap adhesion strength using the Amadeus microkeratome and the IntraLase iFS femtosecond laser in rabbits. J Refract Surg. 2008;24(9):875-878.

14. Kezirian GM, Stonecipher KG. Comparison of the IntraLase femtosecond laser and mechanical keratomes for laser in situ keratomileusis. J Cataract Refract Surg. 2004;30(4):804-811.

15. Smith RT, Waring GO 4th, Durrie DS, Stahl JE, Thomas P. Corneal endothelial cell density after femtosecond thin-flap LASIK and PRK for myopia: a contralateral eye study. J Refract Surg. 2009;25(12): 1098-1102.

16. Sonigo B, Iordanidou V, Chong-Sit D, et al. In vivo corneal confocal microscopy comparison of intralase femtosecond laser and mechanical microkeratome for laser in situ keratomileusis. Invest Ophthalmol Vis Sci. 2006;47(7):2803-2811.

17. Lubatschowski H. Overview of commercially available femotosecond lasers in refractive surgery. J Refract Surg. 2008;24(1):S102-S107.

18. Netto MV, Mohan RR, Medeiros FW, et al. Femtosecond laser and microkeratome corneal flaps: comparison of stromal wound healing and inflammation. J Refract Surg. 2007;23(7):667-676.

19. de Medeiros FW, Kaur H, Agrawal V. Effect of femtosecond laser energy level on corneal stromal cell death and inflammation. J Refract Surg. 2009;25(10):869-874.

20. Tomita M, Chiba A, Matsuda J, Nawa Y. Evaluation of LASIK treatment with the Femto LDV in patients with corneal opacity. J Refract Surg. 2012;28(1):25-30.

21. Sheng H, Bullimore MA. Factors affecting corneal endothelial morphology. Cornea. 2007;26(5):520-525.

22. Wiffen SJ, Hodge DO, Bourne WM. The effect of contact lens wear on the central and peripheral corneal endothelium. Cornea. 2000;19(1): 47-51.

23. Sibug ME, Datiles MB 3rd, Kashima K, McCain L, Kracher G. Specular microscopy studies on the corneal endothelium after cessation of contact lens wear. Cornea. 1991;10(5):395-401.

24. Amoozadeh J, Aliakbari S, Behesht-NejadAH, Seyedian MA, Rezvan B, Hashemi H. Confocal microscopy of corneal stroma and endothelium after LASIK and PRK. J Refract Surg. 2009;25(Suppl 10): S963-S967. 
25. Trocmé SD, Mack KA, Gill KS, Gold DH, Milstein BA, Bourne WM. Central and peripheral endothelial cell changes after excimer laser photorefractive keratectomy for myopia. Arch Ophthalmol. 1996; 114(8):925-928.
26. Patel SV, Bourne WM. Corneal endothelial cell loss 9 years after excimer laser keratorefractive surgery. Arch Ophthalmol. 2009;127(11): $1423-1427$.

\section{Publish your work in this journal}

Clinical Ophthalmology is an international, peer-reviewed journal covering all subspecialties within ophthalmology. Key topics include: Optometry; Visual science; Pharmacology and drug therapy in eye diseases; Basic Sciences; Primary and Secondary eye care; Patient Safety and Quality of Care Improvements. This journal is indexed on
PubMed Central and CAS, and is the official journal of The Society of Clinical Ophthalmology (SCO). The manuscript management system is completely online and includes a very quick and fair peer-review system, which is all easy to use. Visit http://www.dovepress.com/ testimonials.php to read real quotes from published authors. 